\title{
Isolation of Sesquiterpenoids and Steroids from the Soft Coral Sinularia brassica and Determination of Their Absolute Configuration
}

\author{
Giang Nam Pham ${ }^{1}\left(\mathbb{D}\right.$, Da Yeun Kang ${ }^{1}$, Min Ju Kim ${ }^{2}$, Se Jong Han ${ }^{2,3}$, Jun Hyuck Lee ${ }^{3,4}$ and MinKyun Na ${ }^{1, *(\mathbb{C}}$ \\ 1 College of Pharmacy, Chungnam National University, Daejeon 34134, Korea; \\ PhamGiangNam_Y1@hus.edu.vn (G.N.P.); dykang@o.cnu.ac.kr (D.Y.K.) \\ 2 Division of Life Sciences, Korea Polar Research Institute, Incheon 21990, Korea; \\ mjkim1113@kopri.re.kr (M.J.K.); hansj@kopri.re.kr (S.J.H.) \\ 3 Department of Polar Sciences, University of Science and Technology, Incheon 21990, Korea; \\ junhyucklee@kopri.re.kr \\ 4 Research Unit of Cryogenic Novel Material, Korea Polar Research Institute, Incheon 21990, Korea \\ * Correspondence: mkna@cnu.ac.kr; Tel.: +82-42-823-6566
}

Citation: Pham, G.N.; Kang, D.Y.; Kim, M.J.; Han, S.J.; Lee, J.H.; Na, M. Isolation of Sesquiterpenoids and Steroids from the Soft Coral Sinularia brassica and Determination of Their Absolute Configuration. Mar. Drugs 2021, 19, 523. https://doi.org/ $10.3390 /$ md19090523

Academic Editor: Hee Jae Shin

Received: 19 August 2021

Accepted: 15 September 2021

Published: 17 September 2021

Publisher's Note: MDPI stays neutral with regard to jurisdictional claims in published maps and institutional affiliations.

Copyright: (c) 2021 by the authors. Licensee MDPI, Basel, Switzerland. This article is an open access article distributed under the terms and conditions of the Creative Commons Attribution (CC BY) license (https:// creativecommons.org/licenses/by/ $4.0 /)$.
Abstract: Two undescribed rearranged cadinane-type sesquiterpenoids (1-2), named sinulaketol A-B, together with one new chlorinated steroid (3), one new gorgosterol (4), one known sesquiterpene (5), one known dibromoditerpene (6) and two known polyhydroxylated steroids (7-8) were isolated from the soft coral Sinularia brassica. The structures of these compounds were established by extensive spectroscopic analysis, including HRESIMS, 1D, and 2D NMR spectroscopy. Their absolute configurations were also determined by the ECD calculations and DP4+ probability analysis. Antileishmanial activity of compounds 1-8 was evaluated in vitro against the amastigote forms of Leishmania donovani, in which compounds 3, 6, and 7 inhibited the growth of L. donovani by 58.7, 74.3, $54.7 \%$, respectively, at a concentration of $50 \mu \mathrm{M}$. Antimicrobial effect of the isolated compounds were also evaluated against Candida albicans, Staphylococcus aureus, and Escherichia coli. Compound 6, a brominated diterpene, exhibited antimicrobial effect against $S$. aureus.

Keywords: Sinularia brassica; sesquiterpenoids; steroids; antileishmanial activity; antimicrobial activity

\section{Introduction}

Soft corals of the genus Sinularia, which belong to the order Alcyonacea, are important sources of bioactive natural products and have been the target of study since the middle of twentieth century. Numerous secondary metabolites have been isolated from various Sinularia species, particularly sesquiterpenoids, steroids, diterpenoids, and others [1-5]. There is a hypothesis that constituents from soft corals may possess remarkable bioactivities, because their derivatives may act as chemical defense compounds against their predators in various marine ecological environment, to ensure their protection and survival [6]. The object of our study S. brassica is an invertebrate which is widely distributed in the Red Sea and Indo-Pacific. To date, only limited steroids, which belong to the withanolide, ergostane, and pregnene type, have been reported in earlier studies on this species [7,8]. Therefore, a further chemical investigation may likely discover more interesting compounds from the soft coral S. brassica. Our investigation on the chemical compositions of S. brassica had led to the discovery of two undescribed rearranged cadinane-type sesquiterpenoids (1-2), one new chlorinated steroid (3), one new gorgosterol (4) (Figure 1), one known sesquiterpene (5), one known dibromoditerpene (6) and two known polyhydroxylated steroids (7-8). The structures of these compounds were established by spectrometric and spectroscopic approaches, quantum mechanics-based chemical shifts calculation with support of the DP4+ probability analysis, and comparison with previous literature. The antileishmanial activity of compounds 1-8 was evaluated in vitro against $L$. donovani amastigote forms. In 
addition, the antimicrobial activities of all the isolates were tested against Candida albicans, Staphylococcus aureus, and Escherichia coli.
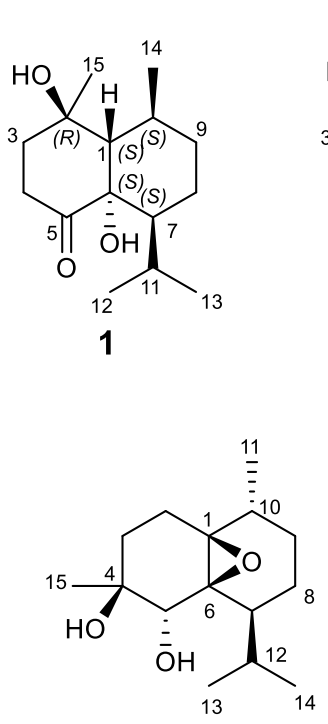

5
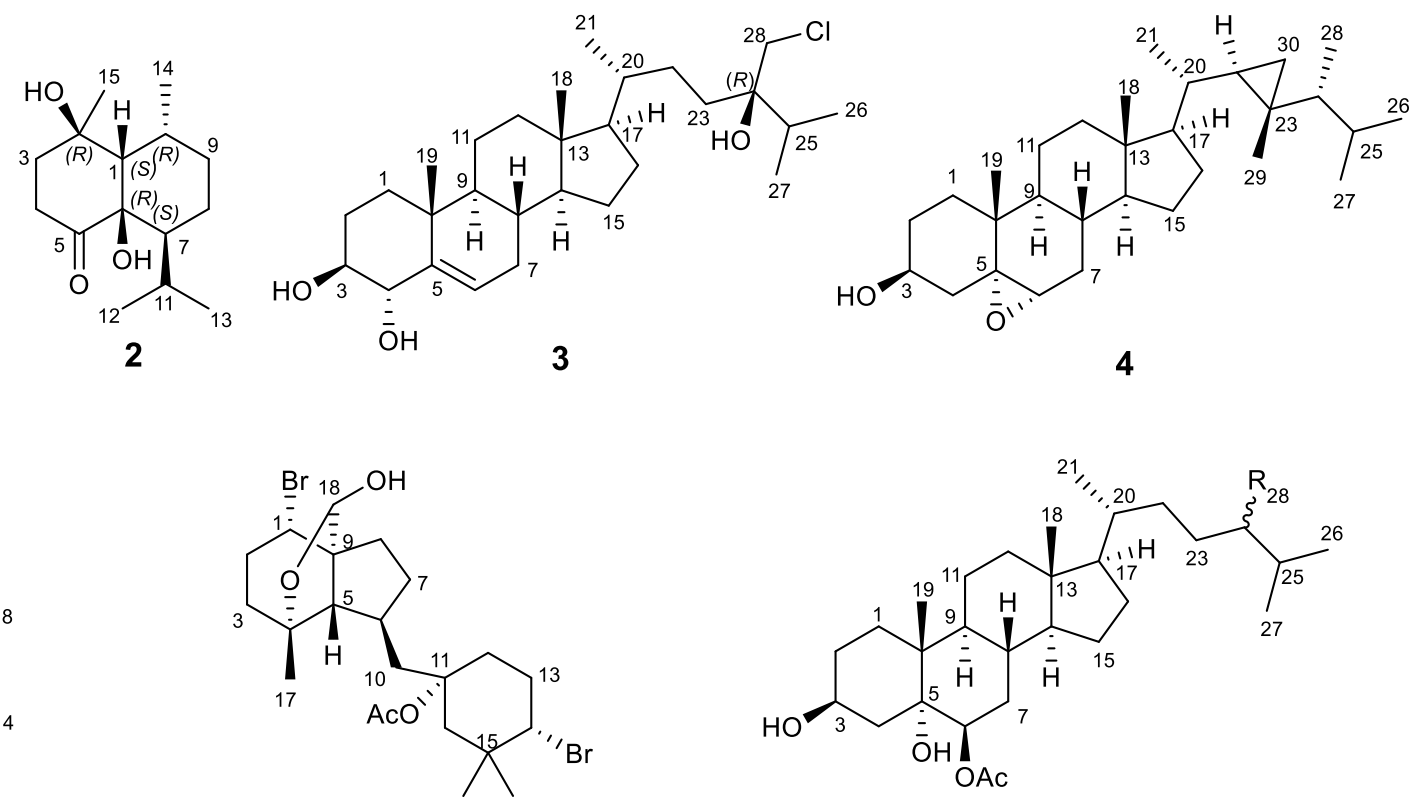

7: $\mathrm{R}=\mathrm{CH}_{2}$
8: $\mathrm{R}=\mathrm{CH}_{3}$

Figure 1. Structures of compounds 1-8 isolated from the Sinularia brassica.

\section{Results}

Compound 1 was obtained as colorless gum. The HRESIMS spectrum of $\mathbf{1}$ exhibited a sodium adduct ion peak at $\mathrm{m} / z 277.1782[\mathrm{M}+\mathrm{Na}]^{+}$(calcd for $\mathrm{C}_{15} \mathrm{H}_{26} \mathrm{O}_{3} \mathrm{Na}^{+}$277.1774) (Figure S1), indicating the molecular formula $\mathrm{C}_{15} \mathrm{H}_{26} \mathrm{O}_{3}$. The ${ }^{1} \mathrm{H}-\mathrm{NMR}$ spectrum of $\mathbf{1}$ in $\mathrm{CDCl}_{3}$ (Table 1, Figure S3) exhibited signals ascribed to an isopropyl group at $\delta_{\mathrm{H}} 1.76(\mathrm{~m}$, $\mathrm{H}-11$ ), 0.95 and 0.72 (each $\mathrm{d}, J=6.5 \mathrm{~Hz}, \mathrm{H}-12$ and $\mathrm{H}-13$ ), two other methyl groups at $\delta_{\mathrm{H}}$ $1.43(\mathrm{~s}, \mathrm{H}-15)$ and $1.16(\mathrm{~d}, \mathrm{~J}=6.5 \mathrm{~Hz}, \mathrm{H}-14)$. The evidence of the placement of ketone group was provided by the deshielded chemical shift of the proton resonance of $\mathrm{H}-4$ at $\delta_{\mathrm{H}} 2.75$ $(\mathrm{ddd}, J=15.3,9.6,4.7 \mathrm{~Hz})$ and $2.53(\mathrm{ddd}, J=15.3,8.9,4.3 \mathrm{~Hz})$ which were ascribable to a neighboring group effect from a ketone group. Fifteen carbon signals were observed in the ${ }^{13} \mathrm{C}-\mathrm{NMR}$ spectrum of $\mathbf{1}$, including one ketone group $\left(\delta_{C} 213.5, C-5\right)$, two quaternary oxygenated carbons $\left(\delta_{C} 72.9,77.5, C-2\right.$ and $C-6$, respectively), and twelve other resonances which were classified unambiguously by HSQC analysis as four methyls, four methylenes, and four methines (Figure S6). The substituted moieties of $\mathbf{1}$ were similar to those of cadinanes, but COSY and HMBC analysis suggested a different skeleton. The locations of the methyl group at $\mathrm{C}-10$ and the isopropyl group at $\mathrm{C}-7$ were determined by COSY spectrum with a continuous spin system from H-1-H-10-H-9-H-8-H-7-H-11-H-12, H-14-H10 and $\mathrm{H}-11-\mathrm{H}-13$ (Figure S5); and the strong HMBC correlations of $\mathrm{H}-14\left(\delta_{\mathrm{H}} 1.16\right)$ to $\mathrm{C}-1$ $\left(\delta_{C} 51.0\right), C-10\left(\delta_{C} 29.1\right), C-9\left(\delta_{C} 31.2\right)$, and H-12 $\left(\delta_{H} 0.95\right), H-13\left(\delta_{H} 0.72\right)$ to $C-7\left(\delta_{C} 47.9\right)$, $\mathrm{C}-11\left(\delta_{C} 26.5\right)$ (Figure $\left.\mathrm{S7}\right)$. Interestingly, the HMBC spectrum showed cross-peaks between $\mathrm{H}-15\left(\delta_{\mathrm{H}} 1.43\right)$ and $\mathrm{C}-3\left(\delta_{\mathrm{C}} 39.7\right), \mathrm{C}-2\left(\delta_{\mathrm{C}} 72.9\right), \mathrm{C}-1\left(\delta_{\mathrm{C}} 51.0\right)$, revealed the unusual position of methyl group C-15. This fact suggested that the planar architecture of $\mathbf{1}$ possessed an undescribed rearranged cadinane skeleton. 
Table 1. ${ }^{1} \mathrm{H}$ and ${ }^{13} \mathrm{C}$ NMR data of compound 1.

\begin{tabular}{|c|c|c|c|c|}
\hline No & $\delta_{\mathrm{H}} *(J$ in $\mathrm{Hz})$ & $\delta_{C} *$ & $\delta_{\mathrm{H}} \#(J$ in $\mathrm{Hz})$ & $\delta_{C} \#$ \\
\hline 1 & $1.81(\mathrm{br} \mathrm{d}, 11.0)$ & 51.0 & $1.55(\mathrm{br} \mathrm{d}, 11.0)$ & 50.7 \\
\hline 2 & - & 72.9 & - & 70.7 \\
\hline 3 & $\begin{array}{c}1.99(\mathrm{~m}) \\
1.90(\mathrm{ddd}, 14.0,9.6,4.3)\end{array}$ & 39.7 & $\begin{array}{l}1.80(\mathrm{~m}) \\
1.74(\mathrm{~m})\end{array}$ & 40.1 \\
\hline 4 & $\begin{array}{l}2.75(\mathrm{ddd}, 15.3,9.6,4.7) \\
2.53(\mathrm{ddd}, 15.3,8.9,4.3)\end{array}$ & 35.4 & $\begin{array}{c}2.52(\mathrm{~m}) \\
2.35(\mathrm{ddd}, 15.8,6.3,4.3)\end{array}$ & 34.6 \\
\hline 5 & - & 213.5 & - & 209 \\
\hline 6 & - & 77.5 & - & 76.2 \\
\hline 7 & $1.72(\mathrm{~m})$ & 47.9 & $1.77(\mathrm{~m})$ & 44.1 \\
\hline 8 & $\begin{array}{c}1.98(\mathrm{~m}) \\
1.62(\mathrm{ddt}, 13.8,4.4,2.3)\end{array}$ & 22.8 & $\begin{array}{c}1.88(\mathrm{~m}) \\
1.41(\mathrm{ddd}, 13.0,4.3,2.0)\end{array}$ & 22.4 \\
\hline 9 & $\begin{array}{l}1.49(\mathrm{~m}) \\
1.30(\mathrm{~m})\end{array}$ & 31.2 & $\begin{array}{c}1.35(\mathrm{ddt}, 11.9,4.9,2.4) \\
1.21(\mathrm{~m})\end{array}$ & 31.2 \\
\hline 10 & $2.12(\mathrm{~m})$ & 29.1 & $2.04(\mathrm{~m})$ & 28.5 \\
\hline 11 & $1.76(\mathrm{~m})$ & 26.5 & $1.68(\mathrm{~m})$ & 26.1 \\
\hline 12 & $0.95(\mathrm{~d}, 6.3)$ & 22.5 & $0.90(\mathrm{~d}, 6.5)$ & 22.7 \\
\hline 13 & $0.72(\mathrm{~d}, 6.5)$ & 23.8 & $0.66(\mathrm{~d}, 6.8)$ & 23.3 \\
\hline 14 & $1.16(\mathrm{~d}, 6.5)$ & 22.7 & $1.06(\mathrm{~d}, 6.5)$ & 22.6 \\
\hline 15 & $1.43(\mathrm{~s})$ & 25.5 & $1.26(\mathrm{~s})$ & 23.1 \\
\hline $\mathrm{OH}-2$ & - & - & 4.14 (br s) & - \\
\hline $\mathrm{OH}-6$ & - & - & 4.79 (br s) & - \\
\hline
\end{tabular}

${ }^{*}$ measured in $\mathrm{CDCl}_{3}$; ${ }^{\#}$ measured in DMSO- $d_{6}$.

The relative configuration of $\mathbf{1}$ was determined by the analyses of coupling constants and the NOESY spectrum (Figure 2). The large coupling constant for $\mathrm{H}-1$ at $\delta_{\mathrm{H}} 1.81$ (br d, $J=11.0 \mathrm{~Hz}$ ) suggested that $\mathrm{H}-1$ and $\mathrm{H}-10$ should in axial positions, supporting a trans-fused ring junction. The NOESY spectrum was measured in DMSO- $d_{6}$ to observe the correlations of hydroxy groups (Figure S17). In particular, the correlations of $\mathrm{H}-10$ with $\mathrm{OH}-6$ and $\mathrm{H}-15$ in the NOESY spectrum permitted both $\mathrm{H}-15, \mathrm{H}-10$ and $\mathrm{OH}-6$ to be oriented on the same side, while the interactions between $\mathrm{H}-1 / \mathrm{H}-11, \mathrm{H}-1 / \mathrm{H}-13$ indicated that they are on the opposite side of the molecule. The absolute configuration of $\mathbf{1}$ was identified by ECD calculations performed by the time-dependent density functional theory (TD-DFT) method. The experimental CD spectrum of $\mathbf{1}$, which showed good agreement with the calculated ECD spectrum for $(1 S, 2 R, 6 S, 7 S, 10 S)$ isomer, and showed mirror-image-like relationship with calculated ECD spectra for $(1 R, 2 S, 6 R, 7 R, 10 R)$ isomer, proved the $(1 S, 2 R, 6 S, 7 S, 10 S)$ absolute configuration for $\mathbf{1}$ (Figure 3 ). Hence, the structure of $\mathbf{1}$ was completely established and named as sinulaketol A.

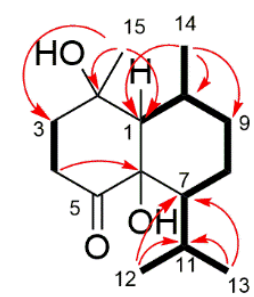

(a)

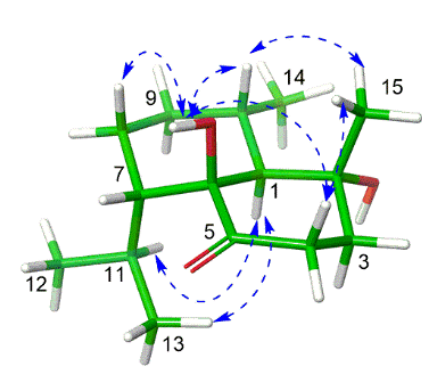

(b)

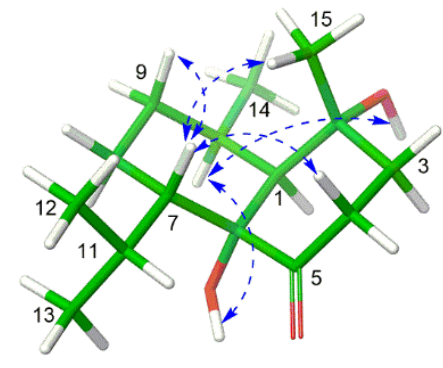

(c)

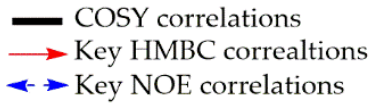

$\leftrightarrow$ Key NOE correlations

Figure 2. (a) Key COSY and HMBC correlations of 1 and 2. (b) and (c) MMFF-energy minimized structures and key NOE correlations of $\mathbf{1}$ and $\mathbf{2}$, respectively.

Compound 2 shared the same molecular formula as $1, \mathrm{C}_{15} \mathrm{H}_{26} \mathrm{O}_{3}$, which was established from HRESIMS data analysis (Figure S18). The 1D and 2D NMR spectroscopic data of 2 (Table 2, Figures S19-S34) were also similar to those of 1, suggesting that compound 2 
possesses the same chemical backbone as $\mathbf{1}$ with different stereochemistry. The coupling constant for $\mathrm{H}-1$ at $\delta_{\mathrm{H}} 2.22(\mathrm{br} \mathrm{d}, J=4.4 \mathrm{~Hz})$ in the ${ }^{1} \mathrm{H}-\mathrm{NMR}$ spectroscopic data in $\mathrm{CDCl}_{3}$ indicated an axial-equatorial relation between $\mathrm{H}-1$ and $\mathrm{H}-10$ (Table 2, Figures 2 and S26). The NOE correlations (in DMSO- $d_{6}$ ) of OH-6/H-10, OH-6/H-1, H-1/OH-2 and H-10/OH-2 indicated that they should be co-facial, suggesting a cis-fused ring (Figure S34). The NOE correlations of $\mathrm{H}-7 / \mathrm{H}-4 \mathrm{a}, \mathrm{H}-7 / \mathrm{H}-15, \mathrm{H}-1 / \mathrm{H}-13$ suggested that the isopropyl group is oriented on the same site with $\mathrm{H}-1$. Consequently, the relative configuration of 2 was reaffirmed as a cis-fused bicyclic system with $1 S^{*}, 2 R^{*}, 6 R^{*}, 7 S^{*}, 10 R^{*}$. The absolute configuration of $\mathbf{2}$ was determined by comparison of experimental ECD data with theoretically calculated ECD curves. The pattern of the experimental ECD spectrum of compound 2 was consistent with the calculated ECD curve for $(1 S, 2 R, 6 R, 7 S, 10 R)$ isomer (Figure 3). Thus, the absolute configuration of compound 2 was determined as $1 S, 2 R, 6 R, 7 S, 10 R$, designated as sinulaketol $\mathrm{B}$.

Table 2. ${ }^{1} \mathrm{H}$ and ${ }^{13} \mathrm{C}$ NMR data of compound 2.

\begin{tabular}{|c|c|c|c|c|}
\hline No & $\delta_{\mathrm{H}} *(J$ in $\mathrm{Hz})$ & $\delta_{C} *$ & $\delta_{\mathrm{H}} \#(J$ in $\mathrm{Hz})$ & $\delta_{C} \#$ \\
\hline 1 & $2.22(\mathrm{~d}, 4.4)$ & 48.6 & $1.85(\mathrm{~m})$ & 48.5 \\
\hline 2 & - & 71.9 & - & 70.0 \\
\hline 3 & $\begin{array}{l}2.01(\mathrm{~m}) \\
1.90(\mathrm{~m})\end{array}$ & 40.6 & $\begin{array}{l}1.75(\mathrm{~m}) \\
1.70(\mathrm{~m})\end{array}$ & 40.7 \\
\hline 4 & $\begin{array}{c}2.66(\mathrm{ddd}, 18.2,8.3,4.5) \\
2.60(\mathrm{~m})\end{array}$ & 35.9 & $\begin{array}{c}2.52(\mathrm{~m}) \\
2.33(\mathrm{ddd}, 18.1,5.7,3.0)\end{array}$ & 35.2 \\
\hline 5 & - & 215.3 & - & 210.3 \\
\hline 6 & - & 79.8 & - & 78.0 \\
\hline 7 & $1.59(\mathrm{~m})$ & 50.8 & $1.73(\mathrm{~m})$ & 46.5 \\
\hline 8 & $\begin{array}{c}2.16(\mathrm{tt}, 14.2,4.2) \\
1.53(\mathrm{~m})\end{array}$ & 19.4 & $\begin{array}{l}2.06(\mathrm{~m}) \\
1.36(\mathrm{~m})\end{array}$ & 18.9 \\
\hline 9 & $\begin{array}{c}1.82(\mathrm{~m}) \\
1.36(\mathrm{dq}, 13.6,3.4)\end{array}$ & 30.2 & $\begin{array}{l}1.76(\mathrm{~m}) \\
1.20(\mathrm{~m})\end{array}$ & 29.9 \\
\hline 10 & $2.44(\mathrm{~m})$ & 28.4 & $2.39(\mathrm{~m})$ & 27.7 \\
\hline 11 & $1.80(\mathrm{~m})$ & 26.7 & $1.74(\mathrm{~m})$ & 26.4 \\
\hline 12 & $0.96(\mathrm{~d}, 6.6)$ & 22.3 & $0.90(\mathrm{~d}, 6.0)$ & 22.8 \\
\hline 13 & $0.71(\mathrm{~d}, 6.7)$ & 24.2 & $0.64(\mathrm{~d}, 6.2)$ & 23.7 \\
\hline 14 & $1.31(\mathrm{~d}, 7.3)$ & 18.5 & $1.25(\mathrm{~d}, 7.2)$ & 19.0 \\
\hline 15 & $1.50(\mathrm{~s})$ & 26.1 & $1.40(\mathrm{~s})$ & 24.9 \\
\hline $\mathrm{OH}-2$ & - & - & $4.37(\mathrm{~s})$ & - \\
\hline $\mathrm{OH}-6$ & - & - & $4.64(\mathrm{~d}, 1.9)$ & - \\
\hline
\end{tabular}

${ }^{*}$ measured in $\mathrm{CDCl}_{3} ;{ }^{\#}$ measured in DMSO- $d_{6}$. 

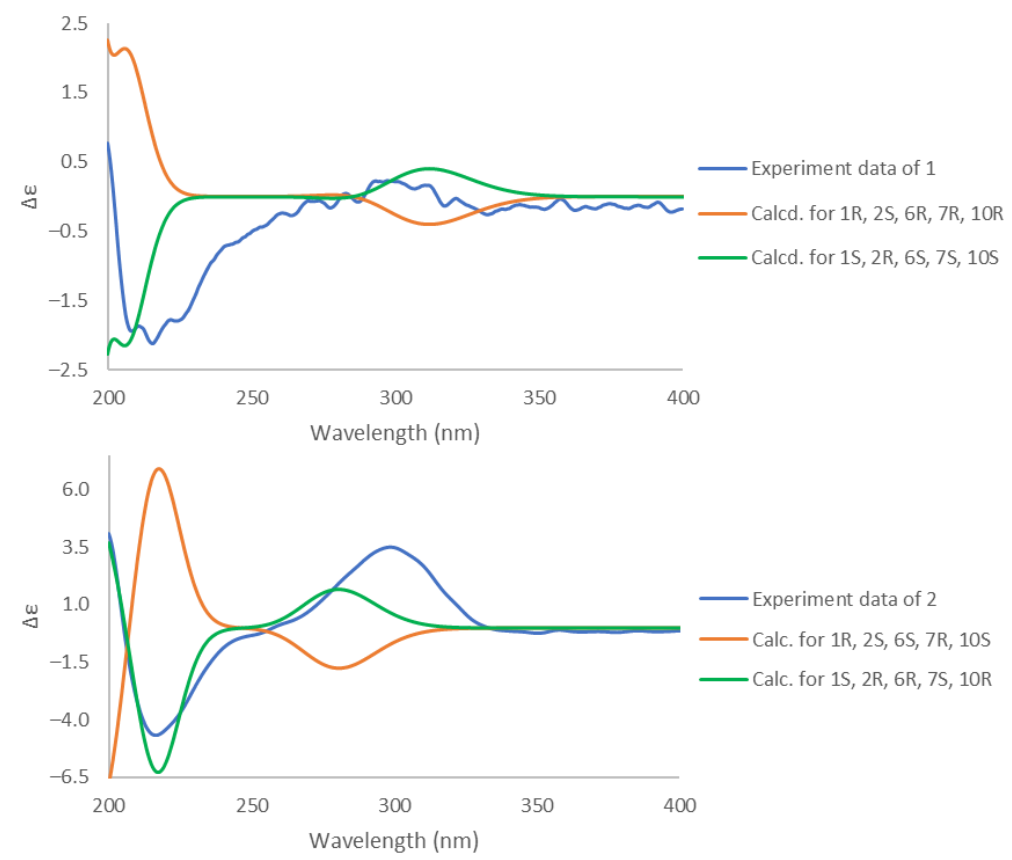

Figure 3. Experimental and calculated ECD spectra of $\mathbf{1}$ and 2.

The molecular formula of compound 3 was identified as $\mathrm{C}_{28} \mathrm{H}_{47} \mathrm{ClO}_{3}$ based on HRESIMS data (Figure S35) at $\mathrm{m} / z 489.3110[\mathrm{M}+\mathrm{Na}]^{+}$(calcd for $\mathrm{C}_{28} \mathrm{H}_{47} \mathrm{ClNaO}_{3}{ }^{+} 489.3106$ ). The ${ }^{1} \mathrm{H}-\mathrm{NMR}$ spectrum of 3 (Figure S36) showed one olefinic proton at $\delta_{\mathrm{H}} 5.74(\mathrm{dt}, J=2.1,4.9 \mathrm{~Hz}$, $\mathrm{H}-6)$, two oxygenated methines at $\delta_{\mathrm{H}} 3.27(\mathrm{ddd}, J=11.3,9.4,4.7 \mathrm{~Hz}, \mathrm{H}-3)$ and $4.06(\mathrm{dd}$, $J=9.4,2.7 \mathrm{~Hz}, \mathrm{H}-4)$, one chlorinated methylene at $\delta_{\mathrm{H}} 3.68(\mathrm{~d}, J=11.2 \mathrm{~Hz}, \mathrm{H}-28 \mathrm{a})$ and $3.56(\mathrm{~d}$, $J=11.2 \mathrm{~Hz}, \mathrm{H}-28 \mathrm{~b})$, and 5 methyl groups at $\delta_{\mathrm{H}} 0.69\left(\mathrm{~s}, \mathrm{H}_{3}-18\right), 1.02\left(\mathrm{~s}, \mathrm{H}_{3}-19\right), 0.93-0,95(9 \mathrm{H}$, overlap, $\mathrm{H}_{3}-21, \mathrm{H}_{3}-26, \mathrm{H}_{3}-27$ ). The ${ }^{13} \mathrm{C}$ and HSQC spectroscopic data (Figures $\mathrm{S} 37$ and $\mathrm{S} 39$ ) indicated that 3 contained five methyls, ten methylenes, nine methines, and four quaternary carbons, suggesting an ergostane-type steroid. The NMR spectroscopic data of the tetracyclic moiety closely resembled those of $3 \beta, 4 \alpha$-dihydroxyergosta-5,24(28)-diene [9], indicating that 3 had two hydroxy groups at $\mathrm{C}-3$ and $\mathrm{C}-4$, and a double bond between $\mathrm{C}-5$ and C-6. The proposed structure was confirmed by COSY data $\left(\mathrm{H}_{2}-1 / \mathrm{H}_{2}-2 / \mathrm{H}-3 / \mathrm{H}-4\right)$, and HMBC correlations of $\mathrm{H}_{3}-19$ to $\mathrm{C}-5$, and $\mathrm{H}-6$ to $\mathrm{C}-4, \mathrm{C}-7, \mathrm{C}-8, \mathrm{C}-10$ (Figure 4a). The relative configuration of 3 was also similar to the reference compound $3 \beta, 4 \alpha$-dihydroxyergosta5,24(28)-diene [9], which was supported by the ${ }^{1} \mathrm{H}-{ }^{1} \mathrm{H}$ coupling constants and NOE analysis. The hydroxyl groups at C-3 and C- 4 were deduced as $\beta$ - and $\alpha$-forms, respectively, by observation of large diaxial coupling constants $(J=9.4 \mathrm{~Hz})$ between $\mathrm{H}-3$ and $\mathrm{H}-4$, and NOE correlations of $\mathrm{H}-4 / \mathrm{H}_{3}-19, \mathrm{H}-3 / \mathrm{H}-1 \alpha, \mathrm{H}-1 \alpha / \mathrm{H}-9$ (Figure $4 b$ ). A chlorinated methylene (C-28) of the side chain in compound 3 was unique, which was confirmed by molecular ion clusters at $m / z 489.3106$ (65\%), 491.3093 (35\%). The location of the chlorinated methylene and oxygenated quaternary carbon were identified by HMBC analysis, where the correlations of $\mathrm{H}_{2}-28$ to $\mathrm{C}-23, \mathrm{C}-24, \mathrm{C} 25$ and $\mathrm{H}_{3}-26, \mathrm{H}_{3}-27$ to $\mathrm{C}-25, \mathrm{C}-24$ were observed. The absolute configuration of $\mathrm{C}-24$ was conducted by the gauge-including atomic orbital (GIAO) NMR chemical shifts calculation supported by DP4+ analysis (Tables S3-S5). The calculated ${ }^{1} \mathrm{H}$ and ${ }^{13} \mathrm{C}$ NMR chemical shifts of the diastereomers $24 S$ and $24 R$ were compared with those of the experimental NMR data of 3 using the advanced statistics DP4+ (Table 3 and Table S5). The DP4 + analyses demonstrated the probability of $24 R$ is $100.0 \%$ (Table 3, Table S5). Consequently, the structure of 3 was elucidated as (24R)-28-chloroergost5-ene-3 $\beta, 4 \alpha, 24$-triol.
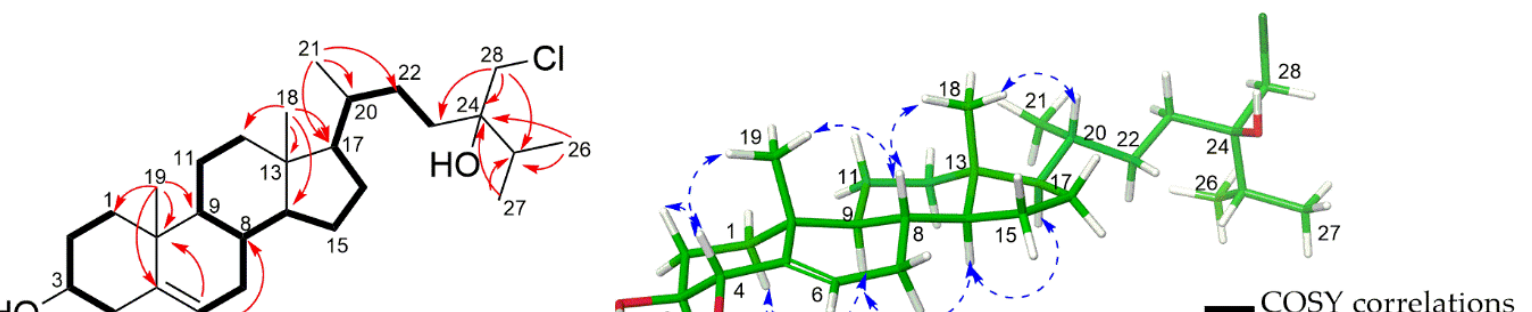
Table 3. DP4+ probabilities for 3.

\begin{tabular}{ccc}
\hline & Isomer 24S & Isomer 24R \\
\hline sDP4+ (H data) & $0.25 \%$ & $99.75 \%$ \\
sDP4+ (C data) & $12.83 \%$ & $87.17 \%$ \\
sDP4+ (all data) & $0.04 \%$ & $99.96 \%$ \\
\hline uDP4+ (H data) & $0.39 \%$ & $99.61 \%$ \\
uDP4+ (C data) & $2.53 \%$ & $97.47 \%$ \\
uDP4+ (all data) & $0.01 \%$ & $99.99 \%$ \\
\hline DP4+ (H data) & $0.00 \%$ & $100.00 \%$ \\
DP4+ (C data) & $0.38 \%$ & $99.62 \%$ \\
DP4+ (all data) & $0.00 \%$ & $100.00 \%$ \\
\hline
\end{tabular}

Compound 4 was obtained as amorphous powder. The molecular formula, $\mathrm{C}_{30} \mathrm{H}_{50} \mathrm{O}_{2}$, was established by quasi-molecular ion peaks at $m / z 465.3705[\mathrm{M}+\mathrm{Na}]^{+}\left(\right.$calcd for $\mathrm{C}_{30} \mathrm{H}_{50} \mathrm{NaO}_{2}{ }^{+}$ 465.3703), $443.3886[\mathrm{M}+\mathrm{H}]^{+}$(calcd for $\left.\mathrm{C}_{30} \mathrm{H}_{51} \mathrm{O}_{2}{ }^{+} 443.3884\right), 425.3779\left[\mathrm{M}-\mathrm{H}_{2} \mathrm{O}+\mathrm{H}\right]^{+}$(calcd for $\mathrm{C}_{30} \mathrm{H}_{49} \mathrm{O}^{+}$425.3778) in HRESIMS data (Figure S46). The ${ }^{1} \mathrm{H}$ NMR spectroscopic data of 4 displayed characteristic proton signals at the very high magnetic field $\delta_{\mathrm{H}^{-}}-0.14(\mathrm{dd}$, $\left.J=5.9,4.3 \mathrm{~Hz}, \mathrm{H}_{\mathrm{a}}-30\right), 0.16(\mathrm{td}, J=8.6,5.7 \mathrm{~Hz}, \mathrm{H}-22), 0.23(\mathrm{dq}, J=9.0,6.9 \mathrm{~Hz}, \mathrm{H}-24)$, $0.45\left(\mathrm{dd}, J=9.1,4.3 \mathrm{~Hz}, \mathrm{H}_{\mathrm{b}}-30\right)$, indicating a cyclopropyl ring in compound 4 [10]. The stereochemistry of the cyclopropyl ring was identical to that in gorgosterols [11]. The upfield shifted oxygen-bearing methine signal at $\delta_{\mathrm{H}} 2.90(\mathrm{~d}, J=4.4 \mathrm{~Hz}, \mathrm{H}-6)$ and the HMBC correlations from H-6 to C-4/C-7/C-8 indicated the presence of an epoxy bridge between C-5 and C-6 (Figure 5). Comparison of the NMR spectroscopic data of 4 with those of synthetic epoxysitosterols revealed the $5 \alpha, 6 \alpha$-orientation [12]. Therefore, 4 was determined to be $5 \alpha, 6 \alpha$-epoxygorgosterol, whose NMR spectroscopic data are shown in Table 4 .

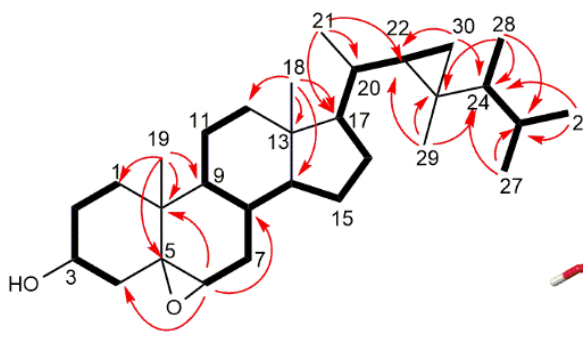

(a)

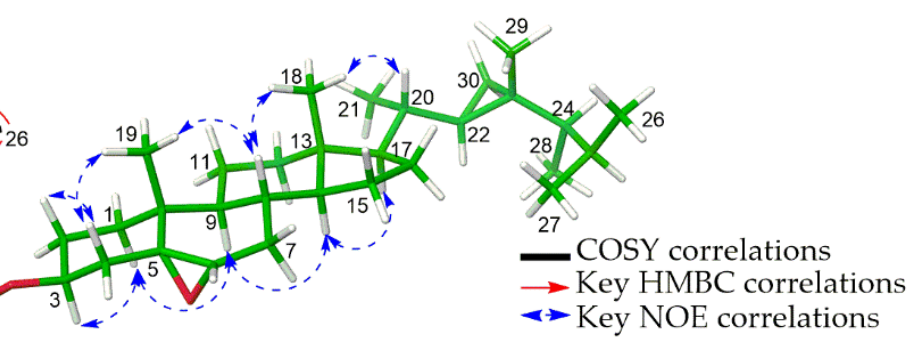

(b)

Figure 5. (a) Key COSY and HMBC correlations of 4. (b) MMFF-energy minimized structure and key NOE correlations of 4.

Table $4 .{ }^{1} \mathrm{H}$ and ${ }^{13} \mathrm{C}-\mathrm{NMR}$ data of compound 3 and 4 in $\mathrm{CDCl}_{3}$.

\begin{tabular}{|c|c|c|c|c|}
\hline \multirow{2}{*}{ No } & \multicolumn{2}{|c|}{3} & \multicolumn{2}{|c|}{4} \\
\hline & $\delta_{\mathbf{H}}(J$ in $\mathbf{H z})$ & $\delta_{C}$ & $\delta_{H}(J$ in $\mathbf{H z})$ & $\delta_{C}$ \\
\hline \multirow{2}{*}{1} & $1.84(\mathrm{~m})$ & \multirow{2}{*}{36.8} & $1.69(\mathrm{~m})$ & \multirow{2}{*}{32.6} \\
\hline & $1.13(\mathrm{~m})$ & & $1.37(\mathrm{~m})$ & \\
\hline \multirow{2}{*}{2} & $1.90(\mathrm{~m})$ & \multirow{2}{*}{28.2} & $1.92(\mathrm{~m})$ & \multirow{2}{*}{31.3} \\
\hline & $1.60(\mathrm{~m})$ & & $1.61(\mathrm{~m})$ & \\
\hline 3 & $3.27(\mathrm{ddd}, 11.3,9.4,4.7)$ & 76.7 & $3.91(\mathrm{tt}, 11.3,4.8)$ & 68.9 \\
\hline 4 & $4.06(\mathrm{dd}, 9.4,2.7)$ & 75.3 & $\begin{array}{c}2.07(\mathrm{dd}, 12.7,11.3) \\
1.30(\mathrm{~m})\end{array}$ & 40.0 \\
\hline 5 & - & 142.1 & - & 65.8 \\
\hline 6 & $5.74(\mathrm{dt}, 2.1,4.9)$ & 117.9 & $2.90(\mathrm{~d}, 4.4)$ & 59.5 \\
\hline \multirow{2}{*}{7} & $2.10(\mathrm{~m})$ & \multirow{2}{*}{31.6} & $1.92(\mathrm{~m})$ & \multirow{2}{*}{29.0} \\
\hline & $1.58(\mathrm{~m})$ & & $1.49(\mathrm{dd}, 15.6,9.9)$ & \\
\hline 8 & $1.44(\mathrm{~m})$ & 31.7 & $1.36(\mathrm{~m})$ & 30.1 \\
\hline 9 & $0.99(\mathrm{~m})$ & 50.6 & $1.25(\mathrm{~m})$ & 42.7 \\
\hline 10 & - & 38.2 & - & 35.0 \\
\hline 11 & $1.49(\mathrm{~m})$ & 21.0 & $1.38(\mathrm{~m})$ & 20.8 \\
\hline \multirow[b]{2}{*}{12} & & \multirow[b]{2}{*}{39.8} & $1.13(\mathrm{~m})$ & \multirow[b]{2}{*}{39.6} \\
\hline & $2.02(\mathrm{~m})$ & & $1.97(\mathrm{~m})$ & \\
\hline 13 & - & 42.4 & - & 42.9 \\
\hline
\end{tabular}


Table 4. Cont

\begin{tabular}{|c|c|c|c|c|}
\hline \multirow{2}{*}{ No } & \multicolumn{2}{|c|}{3} & \multicolumn{2}{|c|}{4} \\
\hline & $\delta_{H}(J$ in $\mathbf{H z})$ & $\delta_{C}$ & $\delta_{H}(J$ in $\mathbf{H z})$ & $\delta_{C}$ \\
\hline 21 & 0.95 (overlap) & 18.9 & 0.97 (br s) & 21.2 \\
\hline 22 & $\begin{array}{l}1.42(\mathrm{~m}) \\
1.07(\mathrm{~m})\end{array}$ & 29.0 & $0.16(\mathrm{td}, 8.6,5.7)$ & 32.2 \\
\hline 23 & $1.70(\mathrm{~m}) ; 1.41(\mathrm{~m})$ & 31.1 & - & 25.9 \\
\hline 24 & - & 75.4 & $0.23(\mathrm{dq}, 9.0,6.9)$ & 50.9 \\
\hline 25 & $1.95(\mathrm{~m})$ & 33.2 & $1.56(\mathrm{~m})$ & 32.2 \\
\hline 26 & 0.93 (overlap) & 16.8 & $0.85(\mathrm{~d}, 6.6)$ & 21.7 \\
\hline 27 & 0.94 (overlap) & 17.2 & $0.94(\mathrm{~d}, 6.7)$ & 22.3 \\
\hline 28 & $\begin{array}{l}3.56(\mathrm{~d}, 11.2) \\
3.68(\mathrm{~d}, 11.2)\end{array}$ & 51.7 & $0.93(\mathrm{~d}, 6.9)$ & 15.6 \\
\hline 29 & - & - & $0.89(\mathrm{~s})$ & 14.4 \\
\hline 30 & - & - & $\begin{array}{c}-0.14(\mathrm{dd}, 5.9,4.3) \\
0.45(\mathrm{dd}, 9.1,4.3)\end{array}$ & 21.4 \\
\hline
\end{tabular}

Four known compounds 5-8 were identified as nanolobatol A (5) [13], pinnaterpene C (6) [14], 24-methylenecholestane-3 $\beta-5 \alpha, 6 \beta$-triol-6-monoacetate (7) $[15,16]$, and cholestane$3 \beta-5 \alpha, 6 \beta$-triol-6-monoacetate (8) [16], respectively.

All the isolates 1-8 were tested in vitro against the amastigote forms of $L$. donovani. Among the compounds 1-8, the new chlorinated steroid (3), dibromoditerpene (6) and the polyhydroxylated steroid (7) inhibited the growth of L. donovani by 58.7, 74.3, and 54.7\%, respectively, at a concentration of $50 \mu \mathrm{M}$, while compounds 3, 6, and 7 did not exhibit cytotoxicity against the THP- 1 cells (Table 5). In addition, all the isolated compounds were evaluated for their antimicrobial activity against Candida albicans, Staphylococcus aureus, and Escherichia coli. Among the tested metabolites, compound $\mathbf{6}$ showed antimicrobial activity against $S$. aureus (Table 5, Figure S51).

Table 5. Antileishmanial and antimicrobial activity of compounds 1-8.

\begin{tabular}{|c|c|c|c|c|c|}
\hline \multirow{3}{*}{ Compound } & \multicolumn{2}{|c|}{ Antileishmanial } & \multicolumn{3}{|c|}{ Antimicrobial } \\
\hline & \multirow{2}{*}{$\begin{array}{l}\text { Inhibition of } \\
\text { Parasites (\%) }\end{array}$} & \multirow{2}{*}{ Cell Viability (\%) ${ }^{b}$} & C. albicans & S. aureus & E. coli \\
\hline & & & \multicolumn{3}{|c|}{$\mathrm{IC}_{50}(\mu \mathrm{g} / \mathrm{mL})$} \\
\hline 1 & -5.3 & 96.2 & $\mathrm{NA}^{\mathrm{c}}$ & NA & NA \\
\hline 2 & 1.4 & 96.5 & NA & NA & NA \\
\hline 3 & 58.7 & 88.8 & NA & NA & NA \\
\hline 4 & -11.9 & 97.1 & NA & NA & NA \\
\hline 5 & -12.3 & 97.0 & NA & NA & NA \\
\hline 6 & 74.3 & 106.2 & NA & $>104$ & NA \\
\hline 7 & 54.7 & 96.1 & NA & NA & NA \\
\hline 8 & 39.0 & 92.7 & NA & NA & NA \\
\hline kanamycin & & & NA & 13.5 & $1.50 \pm 0.24$ \\
\hline nystatin & & & $0.93 \pm 0.18$ & NA & NA \\
\hline
\end{tabular}

${ }^{\mathrm{a}}$ Inhibition of a growth of L. donovani at $50 \mu \mathrm{M},{ }^{\mathrm{b}}$ Cell viability of compounds in THP-1 cell at $50 \mu \mathrm{M}, \mathrm{NA}$ : Not active at $500 \mu \mathrm{g} / \mathrm{mL}$.

\section{Discussion}

As discussed above, we isolated two rare rearranged cadinene-type sesquiterpenoids (1-2) and two new steroids (3-4). Their structures were elucidated by $1 \mathrm{D}\left({ }^{1} \mathrm{H},{ }^{13} \mathrm{C}\right)$ and $2 \mathrm{D}$ NMR experiments (HSQC, HMBC, COSY, and NOESY) and confirmed by HRESIMS. Their absolute configurations were comprehensively established by the ECD calculations and NMR chemical shifts calculations supported by DP4+ analysis.

Sesquiterpenoid is one of the significant metabolites of the genus Sinularia. During the period of 2013-2021, 35 new sesquiterpenes, including four new carbon skeletons, were isolated from this genus [5]. Although new sesquiterpenoids $\mathbf{1}$ and $\mathbf{2}$ belong to cadinane- 
type skeleton, it is the first report on the cadinane sesquiterpenoids with unprecedented carbon backbone at C-15. They might be derived from the cleavage of C1-C6 bond of ylangene-type sesquiterpenoids, rarely found in the soft corals belonging to the genus Dendronephthya and Lemnalia [17-19].

A new chlorinated steroid (3) suppressed the growth of L. donovani by $58.7 \%$ without cytotoxicity (at $50 \mu \mathrm{M}$ ). Pinnaterpene C (6), a dibrominated diterpene, displayed both antileishmanial and antimicrobial activities. This study is the first antileishmanial and antimicrobial investigation for known Pinnaterpene C.

\section{Materials and Methods}

\subsection{General Experiment Procedures}

Vacuum-liquid chromatography (VLC) was conducted on Merck silica gel (70-230 mesh), and Medium-Pressure Liquid Chromatography (MPLC) (Biotage IsoleraTM, Uppsala, Sweden) was performed using Silica gel SNAP cartridge KP-Sil and $\mathrm{C}_{18}$ SNAP cartridge KP-C18-HS (Biotage, Charlotte, NC, USA) at a flow rate of $20 \mathrm{~mL} / \mathrm{min}$. The sample separation was monitored by thin-layer chromatography (TLC). The TLC was performed on glass pre-coated silica gel 60 F254 plates (Merck, Darmstadt, Germany). Reversedphase High-performance liquid chromatography (HPLC) was performed on a Gilson HPLC system (Gilson, Inc. Middleton, WI, USA) with a YMC C 18 Pro Pack $5 \mu \mathrm{m}$ column $\left(250 \times 21.20 \mathrm{~mm}^{2}\right)($ YMC Co., Kyoto, Japan $)$ at a flow rate of $6 \mathrm{~mL} / \mathrm{min} .{ }^{1} \mathrm{H}$ and ${ }^{13} \mathrm{C} \mathrm{NMR}$, and 2D (COSY, HSQC, HMBC and NOESY) NMR spectra were recorded on a Bruker AscendTM 600 MHz (Bruker, Billerica, MA, USA). High-resolution Electrospray Ionization mass (HRESIMS) data were obtained utilizing a Synapt G2 Waters mass spectrometer (Waters, Milford, MA, USA). Optical rotations were obtained on a Jasco DIP-1000 automatic digital polarimeter (Tokyo, Japan). Circular dichroism spectrum was recorded on a Chirascan qCD (Applied Photophysics, Leatherhead, Surrey, UK).

\subsection{Materials and Methods}

The soft coral Sinularia brassica May 1898 was collected in Van Phong bay, Khanh Hoa province, Vietnam in May 2014 and identified by experts at Institute of Oceanography, Nha Trang, Vietnam. A voucher specimen (E54582) was deposited with the Oceanography Museum, Institute of Oceanography in Nha Trang, Vietnam.

\subsection{Extraction and Isolation}

Freeze-dried bodies of the soft coral S. brassica $(6.0 \mathrm{~kg})$ were cut into small pieces and then extracted three times with $\mathrm{MeOH}$ in ultrasonic condition $(1 \mathrm{~h})$ to obtain methanol extract $(257.7 \mathrm{~g})$. The methanol extract was suspended in water and then partitioned with $n$-hexane $(4 \times 2.5 \mathrm{~L})$ to give $n$-hexane soluble fraction $(220.8 \mathrm{~g})$ and water layer. The $n$-hexane fraction was subjected to silica gel VLC $(20 \times 20 \mathrm{~cm})$ and eluted with $n$ hexane/EtOAc $(100: 1 \rightarrow 1: 1)$ and EtOAc/MeOH/ $\mathrm{H}_{2} \mathrm{O}(15: 1: 0.1 \rightarrow 2: 1: 0.3)$ to yield twelve fractions (Fr $1 \sim$ Fr 12). Fraction 5 and 6 were combined $(56.1 \mathrm{~g})$ and further divided by silica gel VLC $\left(12 \times 15 \mathrm{~cm}\right.$, eluting with $\mathrm{CH}_{2} \mathrm{Cl}_{2} / \mathrm{MeOH}(100: 1 \rightarrow 0: 1)$ to give nine fractions (Fr $5.1 \sim$ Fr 5.9). Fraction 5.4 (5.2 g) was separated by RP-MPLC (column: $\mathrm{C}_{18}$ SNAP cartridge KP-C18-HS $120 \mathrm{~g})$ with a stepwise gradient of acetone $/ \mathrm{H}_{2} \mathrm{O}(60: 40,70: 30,75: 25$, 80:20, 90:10, 95:5, 100:0, each 0.3 L) and afforded eight subfractions (Fr 5.4.1 Fr 5.4.8). The subfraction 5.4.2 was further separated by Sephadex LH-20 column chromatography $\left(\mathrm{CC}, 1.5 \times 60 \mathrm{~cm}\right.$ ) eluting with $\mathrm{CH}_{2} \mathrm{Cl}_{2}-\mathrm{MeOH}(2: 1)$ to yield two fractions (Fr 5.4.2.1 Fr 5.4.2.2). Compounds $1\left(t_{R}=44.8 \mathrm{~min}, 2.0 \mathrm{mg}\right)$ and $2\left(t_{R}=40.2 \mathrm{~min}, 2.5 \mathrm{mg}\right)$ were purified from fraction 5.4.2.1 by preparative HPLC [column: YMC $\mathrm{C}_{18}$ Pro Pack $5 \mu \mathrm{m}$ $(250 \times 21.20 \mathrm{~mm})]$ using a mobile phase of $\mathrm{MeOH} / \mathrm{H}_{2} \mathrm{O}(60: 40,6 \mathrm{~mL} / \mathrm{min})$. Compound $5\left(t_{\mathrm{R}}=77.5 \mathrm{~min}, 4.0 \mathrm{mg}\right)$ was purified from fraction 5.4.2.2 by preparative HPLC using $\mathrm{MeOH} / \mathrm{H}_{2} \mathrm{O}(55: 45,6 \mathrm{~mL} / \mathrm{min})$. Subfraction 5.4.6 was further divided into eight fractions (Fr 5.4.6.1 Fr 5.4.6.8) by silica gel CC $(3.0 \times 60 \mathrm{~cm})$ eluting with $n$-hexane/acetone (90:10, 75:25). Fraction 5.4.6.2 was subjected to preparative HPLC using a gradient of 
$\mathrm{MeOH} / \mathrm{H}_{2} \mathrm{O}$ (75:25 for $120 \mathrm{~min}, 75: 25 \rightarrow 100: 0$ for $80 \mathrm{~min}, 6 \mathrm{~mL} / \mathrm{min}$ ) to yield compound 6 $\left(t_{R}=142.5 \mathrm{~min}, 6.5 \mathrm{mg}\right)$. Compound $4\left(t_{R}=65.3 \mathrm{~min}, 5.1 \mathrm{mg}\right)$ was isolated from subfraction 5.4.6.8 by preparative HPLC using $\mathrm{MeOH} / \mathrm{H}_{2} \mathrm{O}(98: 2,6 \mathrm{~mL} / \mathrm{min})$. Fraction 5.6 (2.2 g) was divided into 8 subfractions (Fr 5.6.1 Fr 5.6.8) by NP-MPLC (column: SNAP cartridge KP-Sil $100 \mathrm{~g})$ with a gradient of $n$-hexane/EtOAc $(80: 20 \rightarrow 0: 100)$. Subfraction $5.6 .7(120 \mathrm{mg})$ was separated by Sephadex LH-20 CC with $\mathrm{CH}_{2} \mathrm{Cl}_{2}-\mathrm{MeOH}$ (4:1), yielding five fractions (Fr 5.6.7.1 Fr 5.6.7.5). Compound $3\left(t_{R}=40.7 \mathrm{~min}, 6.6 \mathrm{mg}\right)$ was purified from fraction 5.6.7.2 (15 mg) by preparative HPLC using $\mathrm{MeOH} / \mathrm{H}_{2} \mathrm{O}(90: 10,6 \mathrm{~mL} / \mathrm{min})$. Fraction 5.6.3 and fraction 5.6.4 were combined and separated by preparative $\mathrm{HPLC}$ using $\mathrm{MeOH} / \mathrm{H}_{2} \mathrm{O}$ $(90: 10 \rightarrow 100: 0$ for $120 \mathrm{~min}, 6 \mathrm{~mL} / \mathrm{min})$ to obtain compounds $7\left(t_{R}=98.0 \mathrm{~min}, 26.0 \mathrm{mg}\right)$ and $8\left(t_{R}=109.0 \mathrm{~min}, 9.9 \mathrm{mg}\right)$. Full details of the isolation procedures could be found in Supplementary Materials (Figure S51)

Compound 1: colorless gum; $[a]_{D}^{25}+31.1\left(\right.$ c $\left.0.1, \mathrm{CHCl}_{3}\right) ;{ }^{1} \mathrm{H}$ and ${ }^{13} \mathrm{C}$ NMR data see Table 1; HRESIMS [M+Na] ${ }^{+} \mathrm{m} / z$ 277.1782 (calculated for $\mathrm{C}_{15} \mathrm{H}_{26} \mathrm{O}_{3} \mathrm{Na}^{+}$, 277.1774).

Compound 2: colorless gum; $[a]_{D}^{25}+73.3\left(c 0.08, \mathrm{CHCl}_{3}\right) ;{ }^{1} \mathrm{H}$ and ${ }^{13} \mathrm{C}$ NMR data see Table 2; HRESIMS [M+Na] ${ }^{+} \mathrm{m} / z 277.1782$ (calculated for $\mathrm{C}_{15} \mathrm{H}_{26} \mathrm{O}_{3} \mathrm{Na}^{+}$, 277.1774).

Compound 3: white amorphous powder; $[a]_{D}^{25}-29.7\left(\right.$ c $\left.0.1, \mathrm{CHCl}_{3}\right) ;{ }^{1} \mathrm{H}$ and ${ }^{13} \mathrm{C}$ NMR data see Table 3; HRESIMS [M+Na] ${ }^{+} m / z 489.3110$ (calculated for $\mathrm{C}_{28} \mathrm{H}_{47} \mathrm{ClNaO}_{3}{ }^{+}$ 489.3106).

Compound 4: white amorphous powder; $[a]_{D}^{25}-31.6\left(\right.$ c $\left.0.1, \mathrm{CHCl}_{3}\right) ;{ }^{1} \mathrm{H}$ and ${ }^{13} \mathrm{C} \mathrm{NMR}$ data see Table 3; HRESIMS [M+Na] ${ }^{+} m / z 465.3705$ (calculated for $\mathrm{C}_{30} \mathrm{H}_{50} \mathrm{NaO}_{2}{ }^{+} 465.3703$ ), $[\mathrm{M}+\mathrm{H}]^{+} \mathrm{m} / \mathrm{z} 443.3886$ (calculated for $\mathrm{C}_{30} \mathrm{H}_{51} \mathrm{O}_{2}{ }^{+}$443.3884), $\left[\mathrm{M}-\mathrm{H}_{2} \mathrm{O}+\mathrm{H}\right]^{+} \mathrm{m} / \mathrm{z} 425.3779$ (calculated for $\mathrm{C}_{30} \mathrm{H}_{49} \mathrm{O}^{+} 425.3778$ ).

Nanolobatol A (5): colorless gum; $[a]_{D}^{25}+27.1\left(\right.$ c $\left.0.1, \mathrm{CHCl}_{3}\right) ;{ }^{1} \mathrm{H}$ NMR $(600 \mathrm{MHz}$, $\left.\mathrm{CDCl}_{3}\right) \delta_{\mathrm{H}} 3.75(1 \mathrm{H}, \mathrm{d}, J=9.5 \mathrm{~Hz}, \mathrm{H}-5), 2.39(1 \mathrm{H}, \mathrm{d}, J=10.7 \mathrm{~Hz}, 4-\mathrm{OH}), 2.27(1 \mathrm{H}, \mathrm{pd}, J=6.8$ $3.3 \mathrm{~Hz}, \mathrm{H}-11), 2.04(1 \mathrm{H}, \mathrm{ddd}, J=15.0,5.4,3.2 \mathrm{~Hz}, \mathrm{H}-2 \mathrm{a}), 1.96(1 \mathrm{H}, \mathrm{ddd}, J=9.9,6.3,3.3 \mathrm{~Hz}$, $\mathrm{H}-7), 1.81(1 \mathrm{H}, \mathrm{ddd}, J=15.0,11.5,5.5 \mathrm{~Hz}, \mathrm{H}-2 \mathrm{~b}), 1.79(1 \mathrm{H}, \mathrm{m}, \mathrm{H}-10), 1.55(1 \mathrm{H}, \mathrm{m}, \mathrm{H}-8 \mathrm{~b})$, $1.51(1 \mathrm{H}, \mathrm{m}, \mathrm{H}-3 \mathrm{~b}), 1.45(1 \mathrm{H}, \mathrm{m}, \mathrm{H}-9 \mathrm{~b}), 1.29(1 \mathrm{H}, \mathrm{dddd}, J=14.0,5.5,3.3,1.6 \mathrm{~Hz}, \mathrm{H}-3 \mathrm{a}), 1.26$ (3H, s, H-15), $1.14(1 \mathrm{H}, \mathrm{m}, \mathrm{H}-8 \mathrm{a}), 1.12(1 \mathrm{H}, \mathrm{m}, \mathrm{H}-9 \mathrm{a}), 1.02(3 \mathrm{H}, \mathrm{d}, J=6.8 \mathrm{~Hz}, \mathrm{H}-14), 0.98$ $(3 \mathrm{H}, \mathrm{d}, J=6.9 \mathrm{~Hz}, \mathrm{H}-13), 0.92(3 \mathrm{H}, \mathrm{d}, J=6.8 \mathrm{~Hz}, \mathrm{H}-12) .{ }^{13} \mathrm{C} \mathrm{NMR}\left(150 \mathrm{MHz}, \mathrm{CDCl}_{3}\right) \delta_{\mathrm{c}} 71.0$ (C-1, C-5), 71.0 (C-4), 67.9 (C-6), 42.0 (C-7), 34.6 (C-10), 28.2 (C-11), 27.9 (C-3), 27.8 (C-9), 26.7 (C-15), 24.0 (C-2), 21.9 (C-13), 19.9 (C-8), 17.3 (C-14), 17.2 (C-12); ESI-MS [M+Na] $\mathrm{m} / \mathrm{z} 277.062$

Pinnaterpene C (6): amorphous powder; $[a]_{D}^{25}+8.0\left(\right.$ c $\left.0.1, \mathrm{CHCl}_{3}\right) ;{ }^{1} \mathrm{H} \mathrm{NMR}(600 \mathrm{MHz}$, $\left.\mathrm{CDCl}_{3}\right) \delta_{\mathrm{H}} 5.32(1 \mathrm{H}, \mathrm{s}, \mathrm{H}-18), 4.09(1 \mathrm{H}, \mathrm{dd}, J=11.8,6.1 \mathrm{~Hz}, \mathrm{H}-1), 3.93(1 \mathrm{H}, \mathrm{dd}, J=12.6$, $4.0 \mathrm{~Hz}, \mathrm{H}-14), 2.57(1 \mathrm{H}, \mathrm{dd}, J=14.8,3.6 \mathrm{~Hz}, \mathrm{H}-16 \mathrm{a}), 2.41(1 \mathrm{H}, \mathrm{m}, \mathrm{H}-6), 2.40(1 \mathrm{H}, \mathrm{m}, \mathrm{H}-12 \mathrm{~b})$, 2.23 (2H, overlap, H-2b, H-10b), 2.20 (1H, m, H-13b), 2.08-2.02 (3H, overlap, H-2a, H-7b, H-13a), $2.02(3 \mathrm{H}, \mathrm{s}$, acetyl), $1.88(1 \mathrm{H}, \mathrm{dd}, J=14.4,11.3 \mathrm{~Hz}, \mathrm{H}-10 \mathrm{a}), 1.62(1 \mathrm{H}, \mathrm{m}, \mathrm{H}-3 \mathrm{~b}), 1.60$ $(1 \mathrm{H}, \mathrm{m}, \mathrm{H}-8 \mathrm{~b}), 1.40(1 \mathrm{H}, \mathrm{m}, \mathrm{H}-3 \mathrm{a}), 1.35$ (1H, m, H-12a), $1.34(1 \mathrm{H}, \mathrm{d}, \mathrm{J}=10.7 \mathrm{~Hz}, \mathrm{H}-5), 1.33$ (2H, overlap, H-7a, H-8a), 1.29 (3H, s, H-17), $1.20(1 \mathrm{H}, \mathrm{d}, J=14.8 \mathrm{~Hz}, \mathrm{H}-16 \mathrm{~b}), 1.11(3 \mathrm{H}, \mathrm{s}$, $\mathrm{H}-19), 1.03$ (3H, s, H-20). ${ }^{13} \mathrm{C}$ NMR (150 MHz, $\left.\mathrm{CDCl}_{3}\right) \delta_{\mathrm{c}} 170.9$ (-COO-), 99.1 (C-18), 83.5 (C-11), 83.2 (C-4), 65.1 (C-14), 63.6 (C-5), 62.4 (C-9), 58.9 (C-1), 46.8 (C-16), 45.3 (C-10), 40.8 (C-3), 37.1 (C-12), 36.7 (C-15), 36.1 (C-6), 32.6 (C-2), 32.6 (C-7), 32.6 (C-20), 32.0 (C-8), 30.4 (C-13), 23.0 (C-22), 22.1 (C-17), 21.8 (C-19); ESI-MS [M+Na] ${ }^{+} \mathrm{m} / z 544.925$

24-Methylenecholestane-3 $\beta-5 \alpha, 6 \beta$-triol-6-monoacetate (7): white amorphous powder; $[a]_{D}^{25}-32.4\left(c 0.1, \mathrm{CHCl}_{3}\right) ;{ }^{1} \mathrm{H}$ NMR $\left(300 \mathrm{MHz}, \mathrm{CDCl}_{3}\right) \delta_{\mathrm{H}} 4.71(2 \mathrm{H}, \mathrm{br} \mathrm{s}, \mathrm{H}-6, \mathrm{H}-28 \mathrm{a}), 4.65$ (1H, br s, H-28b), $4.08(1 \mathrm{H}, \mathrm{m}, \mathrm{H}-3), 2.22(1 \mathrm{H}, \mathrm{m}, \mathrm{H}-25), 2.08(1 \mathrm{H}, \mathrm{m}, \mathrm{H}-23 \mathrm{~b}), 2.06(3 \mathrm{H}, \mathrm{s}$, acetyl), $1.15(3 \mathrm{H}, \mathrm{s}, \mathrm{H}-19), 1.01(3 \mathrm{H}, \mathrm{d}, J=6.9 \mathrm{~Hz}, \mathrm{H}-26), 1.01(3 \mathrm{H}, \mathrm{d}, J=6.9 \mathrm{~Hz}, \mathrm{H}-27), 0.93$ $(3 \mathrm{H}, \mathrm{d}, J=6.3 \mathrm{~Hz}, \mathrm{H}-21), 0.68(3 \mathrm{H}, \mathrm{s}, \mathrm{H}-18) .{ }^{13} \mathrm{C} \mathrm{NMR}\left(75 \mathrm{MHz}, \mathrm{CDCl}_{3}\right) \delta_{\mathrm{c}} 170.4$ (-COO-), 157.0 (C-24), 106.1 (C-28), 76.2 (C-6), 75.5 (C-5), 67.4 (C-3), 56.1 (C-17), 56.0 (C-14), 45.5 (C-9), 42.9 (C-13), 40.6 (C-4), 40.0 (C-12), 38.6 (C-10), 35.9 (C-20), 34.8 (C-22), 33.9 (C-25), 32.1 (C-1), 31.1 (C-23), 30.9 (C-2), 30.7 (C-8), 28.3 (C-16), 24.2 (C-15), 22.1 (C-27), 22.0 (C-26), 21.6 (C-11), 21.2 (C-30), 18.8 (C-21), 16.6 (C-19), 12.3 (C-18) 
Cholestane-3 $\beta-5 \alpha, 6 \beta$-triol-6-monoacetate (8): white amorphous powder; $[a]_{D}^{25}-56.0$ (c $\left.0.1, \mathrm{CHCl}_{3}\right) ;{ }^{1} \mathrm{H}$ NMR $\left(300 \mathrm{MHz}, \mathrm{CDCl}_{3}\right) \delta_{\mathrm{H}} 4.71(1 \mathrm{H}$, br s, H-6), $4.08(1 \mathrm{H}, \mathrm{m}, \mathrm{H}-3), 2.01$ (3H, s, acetyl), 1.14 (3H, s, H-19), $0.90(3 \mathrm{H}, \mathrm{s}, \mathrm{H}-21), 0.85(3 \mathrm{H}, \mathrm{d}, J=6.9 \mathrm{~Hz}, \mathrm{H}-26), 0.77(3 \mathrm{H}$, $\mathrm{d}, J=6.8 \mathrm{~Hz}, \mathrm{H}-26), 0.76(3 \mathrm{H}, \mathrm{d}, J=6.8 \mathrm{~Hz}, \mathrm{H}-28), 0.68(3 \mathrm{H}, \mathrm{s}, \mathrm{H}-18) .{ }^{13} \mathrm{C} \mathrm{NMR}(75 \mathrm{MHz}$, $\left.\mathrm{CDCl}_{3}\right) \delta_{\mathrm{c}} 170.4$ (-COO-), 76.2 (C-6), 75.4 (C-5), 67.4 (C-3), 56.1 (C-17), 56.0 (C-14), 45.5 (C-9), 42.9 (C-13), 40.6 (C-4), 40.0 (C-12), 39.2 (C-24), 38.6 (C-10), 36.4 (C-20), 33.8 (C-22), 32.1 (C-1), 31.6 (C-25), 30.9 (C-2), 30.7 (C-8), 30.7 (C-23), 28.3 (C-16), 24.2 (C-15), 21.6 (C-11), 21.2 (C-30), 20.6 (C-26), 19.0 (C-21), 17.7 (C-27), 16.6 (C-19), 15.6 (C-28), 12.3 (C-18)

\subsection{Computational Details}

The conformational searches of each possible isomer were performed by applying 10,000 steps of the Monte Carlo multiple minimum method with PRCG energy minimization using the Merck Molecular Force Field (MMFF) in gas phase to obtain five conformers for each isomer of 1 and 2, 18 and 16 conformers for $24 S$ and $24 R$ isomers of 3 respectively, with a $10 \mathrm{~kJ} / \mathrm{mol}$ energy window limit. Those occurring conformers were then subjected to geometrical optimization and vibrational frequencies calculation using DFT/B3LYP/6-31G(d,p) level with Gaussian 16 package (Gaussian Inc., Wallingford, CT, USA). All optimized structures have no imaginary frequency, and those of compounds 1 and 2 were then proceeded to ECD calculations at TD-DFT/CAM-B3LYP/6-31+G(d,p) (CPCM, acetonitrile) level. ECD curves were Boltzmann averaged and extracted by SpecDis v.1.7 software with half-band of $0.3 \mathrm{eV}$.

The optimized conformers of two possible diastereomers of compound 3 (18 and 16 conformers for $24 S$ and $24 R$ isomers, respectively) were calculated for NMR shielding constants using the gauge-independent atomic orbitals (GIAO) method at the DFT/ rmPW1PW91/6-311+G(d,p) (CPCM, chloroform) level. Chemical shift values were calculated by an equation below where $\delta_{\text {calc }}^{x}$ is the calculated NMR shift for nucleus $x$, and $\sigma^{0}$ is the shielding tensor for the proton or carbon nuclei in tetramethylsilane calculated at the same condition.

$$
\delta_{\text {calc }}^{x}=\frac{\sigma^{0}-\sigma^{x}}{1-\sigma^{0} / 10^{6}}
$$

The calculated NMR properties were averaged based on the Boltzmann populations of all conformers, and the DP4+ probability analysis was conducted using the Excel sheet provided by Grimblat et al $[20,21]$.

\subsection{Biological Assays}

Antileishmanial activity was evaluated according to the protocol of Institut Pasteur Korea [22]. Antimicrobial activity was determined by dropping compounds on agar plate covered with S. aureus KCTC 3881 (bacterium), E. coli DH5 $\alpha$ (bacterium) and C. albicans KCTC 27242 (fungus) (Korean Collection for Type Cultures, Daejeon, Korea). The cell culture was spread on each agar plate up to $10^{8}$ cells/plate, and then $10 \mu \mathrm{L}$ of each compound $(0.3$ and $3 \mathrm{mM})$ dissolved in 50\% DMSO in water were dropped on the plate followed by incubating at $37^{\circ} \mathrm{C}$ for $16 \mathrm{~h}$. Antimicrobial activity was determined by the mark of the cell inhibition. Kanamycin and nystatin were used as positive controls against the bacterium and fungus, respectively. The $\mathrm{IC}_{50}$ values of the compounds were determined using S. aureus KCTC 3881, E. coli DH5 $\alpha$ and C. albicans KCTC 27242 in a 96-well-plate. The cell culture was diluted up to $0.5 \mathrm{McFarland}$ Standard with sterilized media. For C. albicans, the culture broth was 100 times more diluted before use. Each well was filled with $95 \mu \mathrm{L}$ of culture broth. The compounds dissolved in DMSO were added until the final concentrations $(1,2,5,10,20,50,100,200$, and $500 \mu \mathrm{g} / \mathrm{mL})$, and the final volume of each well was $100 \mu \mathrm{L}$ [23]. The plate was incubated at $37^{\circ} \mathrm{C}$ for $16 \mathrm{~h}$. Cell inhibition was measured at $600 \mathrm{~nm}$ (for S. aureus and E. coli) and $530 \mathrm{~nm}$ (for C. albicans) using Multiskan ${ }^{\mathrm{TM}}$ GO Microplate Spectrophotometer (Thermo Scientific, Waltham, MA, USA). The IC 50 value was calculated using an exponential trend line calculated in Excel (Microsoft, Redmond, 
WA, USA). Kanamycin and nystatin were used as positive controls against the bacterium and fungus, respectively.

Supplementary Materials: The following are available online at https://www.mdpi.com/article/ 10.3390/md19090523/s1, Figure S1: HRESIMS of $\mathbf{1}$, Figure S2: ${ }^{1} \mathrm{H}$ NMR spectrum of $\mathbf{1}$ in $\mathrm{CDCl}_{3}$, Figure S3: ${ }^{1} \mathrm{H}$ NMR spectrum of $\mathbf{1}$ in $\mathrm{CDCl}_{3}$ (expanded), Figure S4: $13 \mathrm{C}$ NMR spectrum of $\mathbf{1}$ in $\mathrm{CDCl}_{3}$, Figure S5: COSY spectrum of 1 in $\mathrm{CDCl}_{3}$, Figure S6: HSQC spectrum of 1 in $\mathrm{CDCl}_{3}$, Figure S7: HMBC spectrum of $\mathbf{1}$ in $\mathrm{CDCl}_{3}$, Figure S8: HMBC spectrum of $\mathbf{1}$ in $\mathrm{CDCl}_{3}$ (expanded), Figure S9: ${ }^{1} \mathrm{H}$ NMR data of $\mathbf{1}$ in DMSO- $d_{6}$, Figure S10: ${ }^{1} \mathrm{H}$ NMR data of $\mathbf{1}$ in DMSO- $d_{6}$ (expanded), Figure S11: ${ }^{13} \mathrm{C}$ NMR data of $\mathbf{1}$ in DMSO- $d_{6}$, Figure S12: COSY spectrum of $\mathbf{1}$ in DMSO- $d_{6}$, Figure S13: HSQC spectrum of $\mathbf{1}$ in DMSO- $d_{6}$, Figure S14: HMBC spectrum of $\mathbf{1}$ in DMSO- $d_{6}$, Figure S15: HMBC spectrum of 1 in DMSO- $d_{6}$ expanded, Figure S16: NOESY spectrum of 1 in DMSO-d6, Figure S17: NOESY spectrum of 1 in DMSO- $d_{6}$ (expanded), Figure S18: HRESIMS of 2, Figure S19: ${ }^{1} \mathrm{H}$ NMR data of 2 in $\mathrm{CDCl}_{3}$, Figure S20: ${ }^{1} \mathrm{H}$ NMR data of 2 in $\mathrm{CDCl}_{3}$ (expanded), Figure S21: ${ }^{13} \mathrm{C}$ NMR data of $\mathbf{2}$ in $\mathrm{CDCl}_{3}$, Figure S22: COSY spectrum of $\mathbf{2}$ in $\mathrm{CDCl}_{3}$, Figure S23: HSQC spectrum of $\mathbf{2}$ in $\mathrm{CDCl}_{3}$, Figure S24: $\mathrm{HMBC}$ spectrum of 2 in $\mathrm{CDCl}_{3}$ (expanded-1), Figure S25: HMBC spectrum of $\mathbf{2}$ in $\mathrm{CDCl}_{3}$ (expanded-2), Figure S26: NOESY spectrum of $\mathbf{2}$ in $\mathrm{CDCl}_{3}$, Figure S27: ${ }^{1} \mathrm{H}$ NMR spectrum of 2 in DMSO- $d_{6}$, Figure S28: ${ }^{1} \mathrm{H}$ NMR spectrum of 2 in DMSO- $d_{6}$ (expanded), Figure S29: ${ }^{13} \mathrm{C}$ NMR spectrum of 2 in DMSO- $d_{6}$, Figure S30: COSY spectrum of 2 in DMSO- $d_{6}$, Figure S31: HSQC spectrum of 2 in DMSO- $d_{6}$, Figure S32: HMBC spectrum of 2 in DMSO- $d_{6}$ (expanded-1), Figure S33: HMBC spectrum of 2 in DMSO- $d_{6}$ (expanded-2), Figure S34: NOESY spectrum of 2 in DMSO- $d_{6}$, Figure S35: HRESIMS of 3, Figure S36: ${ }^{1} \mathrm{H}$ NMR data of 3 in $\mathrm{CDCl}_{3}$, Figure S37: ${ }^{13} \mathrm{C}$ NMR data of 3 in $\mathrm{CDCl}_{3}$, Figure S38: COSY spectrum of 3 in $\mathrm{CDCl}_{3}$, Figure S39: HSQC spectrum of 3 in $\mathrm{CDCl}_{3}$, Figure S40: HSQC spectrum of 3 in $\mathrm{CDCl}_{3}$ (expanded), Figure S41: HMBC spectrum of 3 in $\mathrm{CDCl}_{3}$, Figure S42: HMBC spectrum of 3 in $\mathrm{CDCl}_{3}$ (expanded-1), Figure S43: HMBC spectrum of 3 in $\mathrm{CDCl}_{3}$ (expanded-2), Figure S44: NOESY spectrum of 3 in $\mathrm{CDCl}_{3}$, Figure S45: NOESY spectrum of 3 in $\mathrm{CDCl}_{3}$ (expanded), Figure S46: HRESIMS of 4, Figure S47: ${ }^{1} \mathrm{H}$ NMR spectrum of 4 in $\mathrm{CDCl}_{3}$, Figure S48: ${ }^{13} \mathrm{C}$ NMR spectrum of 4 in $\mathrm{CDCl}_{3}$, Figure S49: COSY spectrum of 4 in $\mathrm{CDCl}_{3}$, Figure S50: HSQC spectrum of 4 in $\mathrm{CDCl}_{3}$, Figure S51: HMBC spectrum of 4 in $\mathrm{CDCl}_{3}$, Figure S52: NOESY spectrum of 4 in $\mathrm{CDCl}_{3}$, Figure S53: ESI-MS of 5, Figure S54: ${ }^{1} \mathrm{H}$ NMR spectrum of 5 in $\mathrm{CDCl}_{3}$, Figure S55: ${ }^{13} \mathrm{C}$ NMR spectrum of 5 in $\mathrm{CDCl}_{3}$, Figure S56: ESI-MS of 6, Figure S57: ${ }^{1} \mathrm{H}$ NMR spectrum of $\mathbf{6}$ in $\mathrm{CDCl}_{3}$, Figure S58: ${ }^{13} \mathrm{C}$ NMR spectrum of 6 in $\mathrm{CDCl}_{3}$, Figure S59: ${ }^{1} \mathrm{H}$ NMR spectrum of 7 in $\mathrm{CDCl}_{3}$, Figure S60: ${ }^{13} \mathrm{C}$ NMR spectrum of 7 in $\mathrm{CDCl}_{3}$, Figure S61: ${ }^{1} \mathrm{H}$ NMR spectrum of 8 in $\mathrm{CDCl}_{3}$, Figure S62: ${ }^{13} \mathrm{C}$ NMR spectrum of 8 in $\mathrm{CDCl}_{3}$, Figure S63: Isolation scheme of 1-8, Figure S64: Antimicrobial activity of 1-8, Table S1: Gibbs Free Energy and Boltzmann Population of 1a (4S, $5 R$, $6 R, 9 R, 10 R)$ and $\mathbf{1 b}(4 R, 5 S, 6 S, 9 S, 10 S)$ for ECD computation, Table S2: Gibbs Free Energy and Boltzmann Population of $\mathbf{2 a}(4 S, 5 R, 6 S, 9 R, 10 S)$ and $\mathbf{2 b}(4 R, 5 S, 6 R, 9 S, 10 R)$ for ECD computation, Table S3: Gibbs Free Energy and Boltzmann Population of $24 S$ isomer of 3 for NMR computation, Table S4: Gibbs Free Energy and Boltzmann Population of $24 R$ isomer of 3 for NMR computation, Table S5: Experimental and calculated NMR chemical shift values (ppm) of 3 with diastereomers $24 S$ and $24 R$.

Author Contributions: G.N.P. performed the isolation, structure determination of the compounds, ECD calculations, and wrote the manuscript. D.Y.K. analyzed spectroscopic data and wrote the manuscript. M.J.K., S.J.H., J.H.L. evaluated biological activities. M.N. supervised the experiments and wrote the manuscript. All authors have read and agreed to the published version of the manuscript.

Funding: This research was supported by the project titled "Development of potential antibiotic compounds using polar organism resources (15250103, KOPRI Grant PM21030)", funded by the Ministry of Oceans and Fisheries, Korea.

Institutional Review Board Statement: Not applicable.

Acknowledgments: The authors gratefully acknowledge a grant from the KOPRI (15250103, KOPRI Grant PM21030). We also send special thanks to Institute of Oceanography, Vietnam for providing the samples and Korea Institute of Science and Technology Information (KISTI) for providing the supercomputing resources.

Conflicts of Interest: The authors declare no conflict of interest. 


\section{References}

1. Roy, P.K.; Ashimine, R.; Miyazato, H.; Taira, J.; Ueda, K. Endoperoxy and hydroperoxy cadinane-type sesquiterpenoids from an Okinawan soft coral, Sinularia sp. Arch. Pharmacal Res. 2016, 39, 778-784. [CrossRef] [PubMed]

2. Su, J.H.; Huang, C.Y.; Li, P.J.; Lu, Y.; Wen, Z.H.; Kao, Y.H.; Sheu, J.H. Bioactive cadinane-type compounds from the soft coral Sinularia scabra. Arch. Pharmacal Res. 2012, 35, 779-784. [CrossRef] [PubMed]

3. Lakshmi, V.; Kumar, R. Metabolites from Sinularia species. Nat. Prod. Res. 2009, 23, 801-850. [CrossRef] [PubMed]

4. Blunt, J.W.; Copp, B.R.; Hu, W.P.; Munro, M.H.; Northcote, P.T.; Prinsep, M.R. Marine natural products. Nat. Prod. Rep. 2009, 26, 170-244. [CrossRef] [PubMed]

5. Yan, X.; Liu, J.; Leng, X.; Ouyang, H. Chemical Diversity and Biological Activity of Secondary Metabolites from Soft Coral Genus Sinularia since 2013. Mar. Drugs 2021, 19, 335. [CrossRef] [PubMed]

6. Eskander, R.; Al-Sofyani, A.A.; El-Sherbiny, M.M.; Ba-Akdah, M.A.; Satheesh, S. Chemical Defense of Soft Coral Sinularia polydactyla from the Red Sea Against Marine Biofilm-Forming Bacteria. J. Ocean Univ. China 2018, 17, 1451-1457. [CrossRef]

7. Huang, C.Y.; Liaw, C.C.; Chen, B.W.; Chen, P.C.; Su, J.H.; Sung, P.J.; Dai, C.F.; Chiang, M.Y.; Sheu, J.H. Withanolide-based steroids from the cultured soft coral Sinularia brassica. J. Nat. Prod. 2013, 76, 1902-1908. [CrossRef]

8. Tran, H.H.; Nguyen, V.P.; Nguyen Van, T.; Tran, H.T.; Nguyen Xuan, C.; Nguyen Hoai, N.; Do Cong, T.; Phan Van, K.; Chau Van, M. Cytotoxic steroid derivatives from the Vietnamese soft coral Sinularia brassica. J. Asian Nat. Prod. Res. 2017, 19, 1183-1190. [CrossRef]

9. Ngoc, N.T.; Huong, P.T.; Van Thanh, N.; Cuong, N.X.; Nam, N.H.; Thung, D.C.; Van Kiem, P.; Van Minh, C. Steroid constituents from the soft coral Sinularia nanolobata. Chem. Pharm. Bull. 2016, 64, 1417-1419. [CrossRef]

10. Quang, T.H.; Ngan, N.T.; Van Kiem, P.; Van Minh, C.; Kim, Y.H. A New Sterol from the Soft Coral Lobophytum crassum. Bull. Korean Chem. Soc. 2013, 34, 249-251.

11. Rueda, A.; Zubia, E.; Ortega, M.J.; Salva, J. Structure and cytotoxicity of new polyhydroxylated sterols from the Caribbean gorgonian Plexaurella grisea. Steroids 2001, 66, 897-904. [CrossRef]

12. Zhang, X.; Geoffroy, P.; Miesch, M.; Julien-David, D.; Raul, F.; Aoude-Werner, D.; Marchioni, E. Gram-scale chromatographic purification of $\beta$-sitosterol: Synthesis and characterization of $\beta$-sitosterol oxides. Steroids 2005, 70, 886-895. [CrossRef]

13. Ngoc, N.T.; Huong, P.T.; Thanh, N.V.; Cuong, N.X.; Nam, N.H.; Thung, D.C.; Minh, C.V. Sesquiterpene constituents from the soft coral Sinularia nanolobata. Nat. Prod. Res. 2017, 31, 1799-1804. [CrossRef]

14. Ji, N.Y.; Li, X.M.; Cui, C.M.; Wang, B.G. Terpenes and polybromoindoles from the marine red alga Laurencia decumbens (Rhodomelaceae). Helv. Chim. Acta 2007, 90, 1731-1736. [CrossRef]

15. Li, R.; Shao, C.L.; Qi, X.; Li, X.B.; Li, J.; Sun, L.L.; Wang, C.Y. Polyoxygenated sterols from the South China Sea soft coral Sinularia sp. Mar. Drugs 2012, 10, 1422-1432. [CrossRef]

16. Bortolotto, M.; Braekman, J.C.; Daloze, D.; Tursch, B. Chemical studies of marine invertebrates. XVIII. Four novel polyhydroxylated steroids from Sinularia dissecta (Coelenterata, Octocorallia, Alcyonacea). Bull. Sociétés Chim. Belg. 1976, 85, 27-34. [CrossRef]

17. Elkhayat, E.S.; Ibrahim, S.R.; Fouad, M.A.; Mohamed, G.A. Dendronephthols A-C, new sesquiterpenoids from the Red Sea soft coral Dendronephthya sp. Tetrahedron 2014, 70, 3822-3825. [CrossRef]

18. Duh, C.Y.; El-Gamal, A.A.; Song, P.Y.; Wang, S.K.; Dai, C.F. Steroids and Sesquiterpenoids from the Soft Corals Dendronephthya gigantea and Lemnalia cervicorni. J. Nat. Prod. 2004, 67, 1650-1653. [CrossRef] [PubMed]

19. Xio, Y.J.; Su, J.H.; Chen, B.W.; Tseng, Y.J.; Wu, Y.C.; Sheu, J.H. Oxygenated ylangene-derived sesquiterpenoids from the soft coral Lemnalia philippinensis. Mar. Drugs 2013, 11, 3735-3741. [CrossRef]

20. Grimblat, N.; Zanardi, M.M.; Sarotti, A.M. Beyond DP4: An improved probability for the stereochemical assignment of isomeric compounds using quantum chemical calculations of NMR shifts. J. Org. Chem. 2015, 80, 12526-12534. [CrossRef]

21. Tuan, N.Q.; Oh, J.; Park, H.B.; Ferreira, D.; Choe, S.; Lee, J.; Na, M. A grayanotox-9(11)-ene derivative from Rhododendron brachycarpum and its structural assignment via a protocol combining NMR and DP4 plus application. Phytochemistry 2017, 133, 45-50. [CrossRef] [PubMed]

22. Hassan, A.H.; Phan, T.N.; Yoon, S.; Lee, C.J.; Jeon, H.R.; Kim, S.H.; No, J.H.; Lee, Y.S. Pyrrolidine-based 3-deoxysphingosylphosphorylcholine analogs as possible candidates against neglected tropical diseases (NTDs): Identification of hit compounds towards development of potential treatment of Leishmania donovani. J. Enzym. Inhib. Med. Chem. 2021, 36, 1922-1930. [CrossRef] [PubMed]

23. Jorgensen, J.H.; Doern, G.V.; Maher, L.A.; Howell, A.W.; Redding, J.S. Antimicrobial resistance among respiratory isolates of Haemophilus influenzae, Moraxella catarrhalis, and Streptococcus pneumoniae in the United States. Antimicrob. Agents Chemother. 1990, 34, 2075-2080. [CrossRef] [PubMed] 